\title{
Pilgrims and Missionaries of Social Peace: Geneva and Pontigny as Sites of Scandinavian Internationalism in Late Interwar Europe
}

\author{
Andreas Mørkved Hellenes
}

\begin{abstract}
This article investigates two interlinked sites of Scandinavian socialist internationalism in continental Europe: the Nordic folk high school in Geneva and the humanistic centre created by French philosopher Paul Desjardins in Pontigny. Locating and situating these two nodes on the cultural-political map of late interwar Europe allows for a study of how actors from the popular movements in Denmark, Norway and Sweden mobilised educational ideals and practices to internationalise the experience of Scandinavian social democracy. The analysis shows how the transnational activities of the Nordic folk high school's study course opened up new spaces for Scandinavian internationalism. In this way, the article argues, the school represented an experiment in internationalism from below where Nordism was deployed as a cultural strategy to create international understanding for working-class Scandinavians; and created new arenas for Nordic encounters with French political and intellectual milieus that admired Scandinavian democracy and social peace.
\end{abstract}

Keywords • internationalism, social democracy, Nordism, workers' education, cultural encounters

In 1931, in the first issue of the peace movement's magazine Mellanfolkligt samarbete, the social democratic vagabond, editor and interpreter Sven Backlund announced the creation of a new Scandinavian initiative in service of internationalism and peace. ${ }^{1}$ At the Swedish labour movement's folk high school in Brunnsvik, Backlund had together with Norwegian journalist Birgit Nissen and Danish educationalist Frederik Begtrup drawn up drafts for a Nordic folk high school in Geneva, open to all, but particularly aimed at the non-academic youth, who for the lack of foreign language skills were unable to follow classes in "international questions" taught at the new institutions on the shores of Lac Leman. The idea had come to him on the night train to Geneva.

[I]n the middle of the night, between Hamburg and Cologne, I was awakened by a thought. Danes, Norwegians and Swedes must out in Europe together to feel for themselves that they belong together. But how? ${ }^{2}$

Research for this article has been funded by Vera och Greta Oldbergs stiftelse, Letterstedtska föreningen, Stockholms Arbetareinstitutsförening, the Nordic research hub ReNEW and the Independent Research Fund Denmark (Project 8018-00023B).

1 Sven Backlund, "Skola i Genève," Mellanfolkligt samarbete 1, April 1931, 27.

2 Ibid. Translations from French and the Scandinavian languages to English are my own.

Andreas Mørkved Hellenes (PhD) is a postdoctoral researcher at Aarhus University, Denmark. Email:amh@cas.au.dk 
Historians have pointed out how the social democratic internationalism of the $1920 \mathrm{~s}$ were championed in the Swedish case by leaders like Branting, Engberg and Sandler, well-versed in European languages and frequent travellers to the League of Nations. As Bo Stråth puts it, "[t]he train to Geneva became a true bridge with Europe."3 The initiators of the new school shared the conviction that this bridge should be opened also to young Scandinavians without similar cultural resources: there was a need to get workers and peasants in direct contact with Geneva and to spread the light "from the North to this broken Europe." the school's ambition to internationalise Scandinavia. On the one hand, it offered new social groups the opportunity to take part in international life, functioning as a school in internationalism with studies in Geneva, trips through Europe and reading weeks in the French philosopher Paul Desjardins' cultural centre in the abbey of Pontigny. On the other hand, the Geneva school internationalised through its openness to students from different social groups a Nordic democratic experience both of peaceful cooperation among neighbouring nations and between classes. ${ }^{5}$ In this way the Scandinavians taking part in the school became at the same time pilgrims and missionaries of social peace in Geneva, Pontigny and Scandinavia.

This article examines through the example of the Geneva school Scandinavian internationalism in the late interwar period. Internationalism is not here studied as the relations between national political parties or through the Labour and Socialist International, ${ }^{6}$ but in terms of movements, exchanges and encounters: what Patrizia Dogliani has referred to as "internationalism as praxis."7 More precisely, the purpose of what follows is to study the role of Scandinavian social democratic internationalists and their educational initiatives in bringing Nordic experiences into the interwar European debates and vice versa. Both the histories of social democratic parties' internationalism and the Nordic folk high school movement have been studied extensively in previous research. This study's contribution is to centre on two entangled sites that articulated a Scandinavian internationalism in Europe, producing new encounters at a critical moment in European history that represented "an age of intense cultural exchange." ${ }^{8}$ Such transnational encounters can be studied as hothouses for intellectual exchange, as a sited form of exchange which was played out on stages that had bearing on the exchanges. ${ }^{9}$ The two sites that will be studied here are the

3 Bo Stråth, "The Swedish Image of Europe as the Other," in Europe and the Other and Europe as the Other, ed. Bo Stråth (Brussels: P.I.E.-Peter Lang, 2000), 361.

4 Backlund (1931), 27.

5 Ludvig Krabbe, "Nordiska folkhögskolan i Genève. Folkhöjskolens tredje kurs," Mellanfolkligt samarbete 10, December 1933, 301-2.

6 Cf. Talbot C. Imlay, The Practice of Socialist Internationalism: European Socialists and International Politics, 1914-1960 (Oxford: Oxford University Press, 2017), 1 ff, and Daniel Laqua, "Democratic Politics and the League of Nations: The Labour and Socialist International as a Protagonist of Interwar Internationalism," Contemporary European History 24, no. 2 (2015), 176 ff.

7 Patrizia Dogliani, "The Fate of International Socialism," in Internationalisms. A Twentieth-Century History, ed. Patricia Clavin and Glenda Sluga (Cambridge: Cambridge University Press, 2017), 55 ff. See also the presentation of recent research on internationalism in Patricia Clavin and Glenda Sluga, "Rethinking the History of Internationalism," in Internationalisms. A Twentieth-Century History, ed. Patricia Clavin and Glenda Sluga (Cambridge: Cambridge University Press, 2017).

8 Carlos Reijnen and Marleen Rensen, "Introduction: European Encounters, Intellectual Exchange and the Rethinking of Europe," European Studies 32 (2014), 13.

9 Ibid., 21-22. 
Nordic folk high school in Geneva and Paul Desjardins' cultural centre in Pontigny. In what ways did the establishment of the Geneva School create new arenas for encounters and learning processes for Scandinavian internationalists? Which transnational actors and sites were involved in these processes? How did the activities and spaces contribute to internationalise the experience of social peace in Scandinavia?

In answering these questions, the article attempts to do two things. Drawing on Norbert Götz' observation that Norden in the interwar period was "constructed" in Geneva through "interaction with outsiders," the article explores an example of everyday cooperation between Nordic actors abroad, with its repercussions both back in Scandinavia and on outside perceptions of the Nordic countries. ${ }^{10}$ Similarly, in a study of the Nordic officials working within the new international bureaucracy staffing the League of Nations, Karen Gram-Skjoldager, Haakon Ikonomou and Torsten Kahlert have pointed out how these were perceived by non-Nordic actors in Geneva as representing a common Scandinavian identity. ${ }^{11}$ At the centre of this article's investigation however we find other social actors than the politicians, diplomats and civil servants representing the Nordic countries in the Genevese institutions, such as educationalists and students, which together constituted the internationalist flanks of the emerging Scandinavian labour movements. ${ }^{12}$ By focusing on these actors and sites, the article furthermore aims to introduce more complexity to the history of what has been referred to as a construction of a foreign and in particular American image of the early Nordic welfare state, and its usage in domestic political debates. ${ }^{13}$ It is important to complement the history of foreign observers going North and bringing ideas home with that of other encounters taking place elsewhere and outside of the Nordic region, and notably in the context of Scandinavia's European connections during the late interwar period. Finally, the article seeks to shed new light on the transnational history of European interwar socialist internationalism by focusing on other social actors than political parties and by complementing a literature dominated by studies of Great Britain, France and Germany; in this body of work the Scandinavian workers' movements are sometimes mentioned but hardly ever present. ${ }^{14}$

The analysis of the Geneva School is based on archival materials kept in the Swedish Labour Archives and Library (ARAB). Specifically, I have considered the

10 Norbert Götz, "'Blue-Eyed Angels' at the League of Nations: The Genevese Construction of Norden," in Regional Cooperation and International Organizations: The Nordic Model in Transnational Alignment, ed. Norbert Götz and Heidi Haggrén (London: Routledge, 2009), 27.

11 Karen Gram-Skjoldager, Haakon A. Ikonomou and Torsten Kahlert, "Scandinavians and the League of Nations Secretariat, 1919-1946," Scandinavian Journal of History 44, no. 4 (2019), 464-66.

12 Although no systematic prosopographical study of these two groups, the analysis is based on a preliminary mapping out of the actors' professional and political profiles.

13 See for example Kazimierz Musial, Roots of the Scandinavian Model: Images of Progress in the Era of Modernisation (Baden-Baden: Nomos-Verlag, 2002); Mary Hilson, "Consumer Co-operation and Economic Crisis: The 1936 Roosevelt Inquiry on Co-operative Enterprise and the Emergence of the Nordic 'Middle Way", Contemporary European History 22, no. 2 (2013); Carl Marklund and Klaus Petersen, "Return to Sender: American Images of the Nordic Welfare States and Nordic Welfare State Branding," European Journal of Scandinavian Studies 43, no. 2 (2013); Kiran Klaus Patel, "How America Discovered Sweden. Reinventing Democracy during the 1930s," in Transatlantic Democracy in the Twentieth Century. Transfer and Transformation ed. Paul Nolte (Berlin: Walter De Gruyter, 2016); Byron Rom-Jensen, "A Model of Social Security? The Political Usage of Scandinavia in Roosevelt's New Deal," Scandinavian Journal of History 42, no. 4 (2017).

14 See for example Laqua (2015), Imlay (2017), and Dogliani (2017). 
organisation protocols pertaining to the school's consolidation, the rectors' yearly reports and the board evaluations of the courses. In order to analyse some of the participating students' experiences I have made use of travel letters published in periodicals and local newspapers. ${ }^{15}$ Finally, the study of the French-Swedish meeting at Pontigny is based on personal papers kept at the Institut Souvarine in Paris; the Swedish LO's archives at ARAB; and the Swedish Employers Association at the Centre for Business History in Stockholm. ${ }^{16}$

The article is structured in four parts. The first situates the Scandinavian internationalism of the Geneva School in relation to previous research about Nordism in the late interwar period. In the second section I turn to the school's activities following its consolidation in 1935, and identify its deployment of Nordism as a cultural strategy used to educate internationalism to the Scandinavian students and give them access to knowledge about the international institutions. I first study how the students experienced the school and its travels around Europe as an encounter with international life. Secondly, I situate it as part of a broader agenda within Scandinavian social democracy where integration of the Norwegian labour movement on the international arena was a priority in a moment where democracy was under threat in Europe. This situation triggered the creation of new connections between transnational progressive alliances in democratic Europe, some through the establishment of cultural exchanges and education, others seeking to overcome the divisions on the labour market. It was further expressed in the episode that I discuss in the following section, namely how the French search for social peace after the fall of the Popular Front culminated in the French-Swedish meeting at Pontigny. Finally, I discuss the meanings of the Geneva School's interwar Nordic internationalism, arguing that it functioned in a dual way that aligned the international outlook with the national agenda and vice versa rather than opposing them. It internationalised those involved in organising, teaching and participating in the school's course, and it internationalised the Scandinavian reformist democratic experience.

\section{The Geneva School: Internationalism in an age of Nordism}

In August 1935 the members of the Association of the Nordic folk high school in Geneva met at Folketeatret in Oslo for their annual general meeting. Founded in 1930-31, the school had been through a tumultuous trial period ridden with organisational conflict. Thoroughly reorganised, it was consolidated in Oslo under the influence of the workers' educational associations (Arbejdernes Oplysningsforbund in Denmark, Arbeidernes Oplysningsforbund in Norway, Arbetarnas Bildningsförbund in Sweden), granted public funds from the three Scandinavian social democratic governments, and allocations from the Nordic cooperative movement (Nordisk

15 I have only used texts that convey the relatively immediate impressions of the students, and not the journalistic stories that some participants sent home. A case in point is Sigurd Evensmo's texts from his time as a student in 1935, where there is no mention of the school, e.g. his reports from the International Labour Conference to the Norwegian labour press, Sigurd Evensmo, "Arme mr. Butler," Arbeiderbladet, July 8, 1935, and Sigurd Evensmo, "Selsom revy over verden i nød: Arbeidskonferansen i Geneve-sett fra galleriet," Arbeiderbladet, June 29, 1935.

16 These include French press clippings that track the debate in France, which were collected and bound by the French organisers and sent as gifts to the two Swedish organisations. 
Andelsforbund) ${ }^{17}$ The reorganisation, proposed by a five-man committee chaired by $\mathrm{ABF}$ secretary Gunnar Hirdman, was an attempt to solve a critical situation for the school. ${ }^{18}$ During its first years it had been the object of internal quarrels and public dispute as a result of a power struggle between Scandinavian officials at the Genevese institutions and the workers' educational organisations in Scandinavia. Historian of ideas Katarina Leppänen has interpreted this quarrel as resulting from two conflicting perspectives on internationalism that time and again surfaced during the school's first years. ${ }^{19}$ Whereas the Geneva officials saw internationalism as represented by the new world order constituted by the League of Nations and the International Labour Organisation, the representatives of the workers' associations adopted a more critical position, related to their stances on nationalism, Nordism, and the possibility of expanding "the power of the small and neutral European states" rather than adapting the worldview of the major powers. ${ }^{20}$ This reflected the emergence of a new answer to a new political situation in Europe with the rise of fascism and communism and the ensuing problems of the contemporary world organisation, and the result was a controversy between two groups, the officials and the Social Democratic teachers. Among the early teachers of the Geneva School were several young, Social Democratic academics: the Swedes Allan Degerman, Gunnar Myrdal, and Oluf Leopold; the Norwegians Axel Sømme, Arne Ording and Halvard Lange; and the Danes Arne Sørensen, Oluf Bertolt, and Sigurd Juul Andersen ${ }^{21}$. When the trio Backlund, Sømme and Sørensen published Den største højttaler, a collection of articles about the place of the Nordic countries in the world in 1933, the conflict had escalated. ${ }^{22}$ Arguing for a "new Scandinavianism" and a socialist reorientation with public measures to fight the oncoming economic crisis, the Geneva teachers quickly

17 "Nordisk Folkehøiskole i Genève: April 1936," protocol from board meeting in Svalöv, April 28, 1936, vol. 1, NFG, ARAB, 3.

18 Along with Hirdman the other members of the committee were the Danes Arne Sørensen and Oluf Bertolt and the Norwegians Christian L. Lange and Haakon Lie.

19 Katarina Leppänen, "Education for Internationalism at the Nordic School for Adult Education in Geneva 1931-1939," History of Education 40, no. 5 (2011), 645-49.

20 Ibid.

21 Allan Degerman (1901-1980) was rector of Viskadalen folk high school from 1926-1933 and one of the pioneers in introducing courses in international questions to the Swedish folk high schools. The economist Gunnar Myrdal (1898-1987) was an associate professor at the Graduate Institute of International Studies in Geneva in 1930-31 and influential social democratic intellectual and politician. Axel Sømme (1899-1991) defended a French doctorate in economic geography in 1931. A member of the intellectual Marxist group Mot Dag before joining the Labour Party, he co-wrote in 1933 the influential En norsk 3-årsplan with Ole Colbjørnsen. Arne Ording (1898-1967) obtained a French doctorate in history in 1930. A member of Mot Dag, he joined the Labour Party in 1936 and was the first editor of the journal Internasjonal Politikk. Halvard Lange (1902-1970) was a grant holder at the Christian Michelsen Institute 1932-1935, secretary at AOF 1935-1936, and rector at Sørmarka folk high school 1938-1940. He was a member of the Labour Party's leadership from 1933. Arne Sørensen (1906-1978) worked at Politiken 1929-1931 and as a folk high school teacher 1930-1936. He broke with the Social Democrats to found a new political party, Dansk Samling, in 1936, advocating a national-Christian "third way" position. Oluf Bertolt (1891-1958) was a folk high school teacher and journalist. He was between 1933-39 the editor of Socialisten, and was rector at Esbjerg workers' folk high school 1934-1957. Sigurd Juul Andersen (1898-1976) was a folk high school teacher. Based at Askov from the mid-1920s, he taught in particular international politics and was a strong believer in the League of Nations.

22 Sven Backlund, Axel Sømme and Arne Sørensen, Den største høittaler og fem andre aktuelle problemer (Oslo: Tiden, 1933). 
found themselves under attack by bourgeois newspapers back home and the Nordic League of Nations' officials in Geneva. ${ }^{23}$

The consolidation of the school at the general meeting in 1935 was effectuated on three levels. On the organisational level it became to a much larger extent linked to the workers' educational associations in Scandinavia and separated from the Geneva officials. Secondly all decisions concerning the school's curriculum and teachers would be decided by an acting board, rather than an annual general meeting. Thirdly and as a result of this, a fixed format was introduced for the annual course that would stay in place until the outbreak of the war. Its outcome was essentially a submission of the school to the workers' educational associations. Moreover, this led to something of a change of guards on the school board. Among the original founders of the school, together with Backlund, had been the Danish League of Nations' employees Ludvig Krabbe and Finn T. B. Friis, the Swedish ILO secretary Sture Thorsson, the Interparliamentary Union's Norwegian secretary general Christian L. Lange, and the Swedish Liberal parliamentarian Kerstin Hesselgren - all of them important names associated with the spirit of Geneva in their home countries. With the Geneva Scandinavians gone, the set-up shifted considerably. Influential men from the workers' educational organisations, such as Hirdman and Bertolt, together with the perennial Backlund and Norwegian LO secretary Lars Evensen, made up a solid majority against the sole representative of classical Grundtivigianism on the Geneva School's board, the Dane Holger Kjær. ${ }^{24}$ On a larger scale, this exemplifies the turn from liberal internationalism to social democratic internationalism in the Nordic countries, with new internationalists imposing themselves: young scholars with an internationalist outlook, socialist ideas, and support from increasingly strong labour movements back home. This shift from the liberal internationalism incarnated by the Geneva officials to a new, social democratic internationalism was perfectly represented by the replacement of Christian L. Lange by his son, historian and secretary of the AOF Halvard Lange, as one of the Norwegian members on the board. From autumn 1935 all three Scandinavian countries had social democratic governments which decided to support the school financially, sometimes to the dismay of other political parties. ${ }^{25}$

Although "Nordic" in the name, the school was by and large a Scandinavian story. The inclusion of Finnish members of the board was discussed, but rejected. ${ }^{26}$ It is however important to point out that the ambition of the Nordic school's Nordism was something quite different from Scandinavianism in the nineteenth century sense of political unity. Nor was it a particularly loose, inclusive vision of Nordic community. Finnish, Icelandic (and Estonian) Scandinavophone students occasionally attended the school's course, but their numbers were minimal compared to the typical twelve-fifteen yearly participants from the Scandinavian countries. Nordism, for the organisers, was less concerned with representativity than with a cultural-political

23 Leppänen (2011), 645.

24 “Foreningen Nordisk Folkehøiskole i Genève. Nov. 1935," protocol from board meeting in Malmö, 22-23 November 1935, vol. 1, NFG, ARAB, 1.

25 “Folkeskolens budgett vedtatt," Nationen, April 4, 1936.

26 "Aarsmöte i Foreningen Nordiske Folkehöiskole i Genève," protocol from annual general meeting in Oslo, August 25 1935, vol. 1, NFG, ARAB, 4. 
programme based on linguistic community. In this sense, it was but one of many expressions of a new wave in the history of workers' Scandinavianism (arbeiderskandinavisme) ${ }^{27}$ Another example of this was the re-creation, in 1932, of the Joint Committee of the Nordic Social Democratic Labour Movement (SAMAK), that sought to coordinate the work of the labour movement committees formed by unions and parties and grew in importance as the social democratic parties came into government. ${ }^{28}$ Mirja Österberg has argued that SAMAK played an important role as the transnational agent in the construction of a Nordic region, producing in the 1930s a "negotiated consensus on Nordicness," influential in bringing the Norwegian labour movement back into the fold. ${ }^{29}$ Similarly, it has been argued that the Nordic folk school in Geneva played a part in helping the Norwegian labour movement's return along the "long way to Geneva." ${ }^{30}$ The Norwegian participation at the International Labour Conference in 1934, which marked the return of Norway to the ILO after some fifteen years of scepticism towards the organisation, opened the door for other forms of international cooperation. Soon after reintegrating the ILO, Norwegian LO joined the Amsterdam International and SAMAK, indicating their revised positions on international matters as well as a newfound confidence in government along with a need to mobilise in defence of democracy. ${ }^{31}$

Workers' Scandinavianism came to be based on practical co-operation and cultural affinities that in the 1930 s could be summed up in precisely that word: democracy - "democracy within and between the people; social, political, economic, national, Scandinavian and international democracy," as Per Albin Hansson defined it in a speech in Copenhagen. ${ }^{32}$ This was the fruit of the labour of the workers' movements, and decidedly different from earlier forms of Scandinavianism, according to Norwegian Arbeiderbladet upon the celebration of the Day of Norden: "Whereas the previous academic-literary "Scandinavianism" with its foggy pathos never got any practical impact and died a quiet death, the Nordic workers' front has stood strong and delivered practical results." ${ }^{33}$ One expression of this new Nordism, which became central in social democratic rhetoric in the late 1930s, was the concept "Nordic democracy." Again, it drew meaning from its contrast with bourgeois democracy, positing parliamentary democracy as a stage in political progress that

27 Mary Hilson, Silke Neunsinger, Iben Vyff and Ragnheidur Kristjánsdóttir, "Labour, unions and politics in the Nordic countries, c. 1700-2000: Introduction," in Labour, Unions and Politics under the North Star: The Nordic Countries, 1700-2000 ed. Mary Hilson, Silke Neunsinger and Iben Vyff (New York/Oxford: Berghahn Books, 2017), 8, 16.

28 Klaus Petersen, "Constructing Nordic Welfare? Nordic Social Political Cooperation 1919-1955," in The Nordic Welfare State: A Historical Reappraisal, ed. Niels Finn Christiansen, Nils Edling, Per Haave and Klaus Petersen (Copenhagen: Museum Tusculanum, 2006), 73.

29 Mirja Österberg, “Norden' as a Transnational Space in the 1930s: Negotiated Consensus of 'Nordicness' in the Nordic Cooperation Committee of the Labour Movement," in Labour, Unions and Politics under the North Star: The Nordic Countries, 1700-2000 ed. Mary Hilson, Silke Neunsinger and Iben Vyff (New York/Oxford: Berghahn Books, 2017), 237.

30 Halldor Heldal, "Den lange veien til Genève: Norsk arbeiderbevegelse og ILO 1920-1934," Arbeiderhistorie 5 (1992).

31 Kettunen (2013), 215.

32 Ruth Hemstad, "Scandinavianism, Nordic Co-operation, and 'Nordic Democracy"' in Rhetorics of Nordic Democracy, ed. Jussi Kurunmäki and Johan Strang (Helsinki: Finnish Literature Society, 2010), 189-90.

33 "Vekst og grotid for samholdstanken i Norden," Arbeiderbladet, 26 October, 1936. 
was to be defended so that it would be possible to take more steps towards a full democracy. The concept of 'Nordic democracy', first launched in 1935, arose as a domestic and Nordic answer to the increasingly menacing outside "world of tensions," and was used to mobilise large crowds in public celebrations. ${ }^{34}$

These examples show that Norden in various ways was used in the Nordic social democratic context as a resource. ${ }^{35}$ From the mid-1930s, the Geneva School represented a similar position on Nordism as a political strategy. With the introduction of new statutes and a new board consisting mainly of representatives of the educational associations, the school's organisational ties to the Geneva Scandinavians were broken. This did not seem to cause a setback for the school's popularity. To the contrary, the consolidation represented a "full breakthrough" with great interest from prospective students, although it made it decidedly more social democratic. ${ }^{36}$ While Ludvig Krabbe in 1933 had observed a sometimes difficult political diversity among students "[f]rom fascists to left wing socialists, conservative liberalism, but mainly traditional socialism — which doesn't exclude strong nationalism-creating tensions between nationalities," ${ }^{37}$ the political homogeneity within the group was highlighted four years later. ${ }^{38}$

\section{Nordism as a cultural strategy of Scandinavian internationalism}

From the consolidation the Geneva School's programme consisted of four dimensions. First, a period of pre-school preparation in the Nordic countries, based on the methods of the popular educational movements like correspondence courses with preparatory readings. Then the participants met for a preparatory taught programme at folk high schools in Scandinavia. Secondly an important place on the programme was occupied by travels around Europe providing a practical look on contemporary Europe and its economy, industry, social relations, politics and ideologies. Thirdly the Geneva weeks, filled with taught classes and visits to the institutions. And finally, some weeks to finish the courses and digest the experiences at Pontigny before the return home. Jenny Jansson has argued in her studies of workers' education that it can be seen to constitute "a forum for ideological schooling of members that can be and has been identity-constitutive." ${ }^{39}$ Which identities did the educational programmes of the Nordic folk high school constitute? The question of the relationship between Nordism and internationalism was in this context a practical just as much as a theoretical concern; one could perhaps say that it was deployed as a cultural strategy. A cornerstone of the school had since its creation been that teaching should take place in Danish, Norwegian, Swedish on equal footing. Teaching materials in the vernacular languages were a constant preoccupation due to the lack of textbooks on

34 Jussi Kurunmäki and Johan Strang. "Introduction: 'Nordic Democracy' in a World of Tensions," in Rhetorics of Nordic Democracy, ed. Jussi Kurunmäki and Johan Strang (Helsinki: Finnish Literature Society, 2010).

35 Österberg (2017), 238.

36 Kerstin Hesselgren, “Nordiska folkhögskolan i Genève," Mellanfolkligt samarbete 2, 1935, 57-58.

37 Krabbe (1933), 301.

38 Benjamin Bjørklund, “Seks sommer-uker ved Geneve-sjøen,” Bergens Tidende, July 14, 1937.

39 Jenny Jansson, "Class Formation in Sweden and Britain: Educating Workers," International Labor and Working-Class History 90, fall (2016), 52. 
international questions available in Scandinavia, and the "pooling" of resources from the three countries improved the situation considerably. Most importantly however the language policy of the school expressed a democratic and social ambition, emphasising the opportunity to acquire knowledge and experiences outside of the national framework for those that had no academic training nor foreign language skills. In other words, Nordism made an internationalism from below possible in the Nordic context. As Axel Sømme, rector of the school from 1933-1935, put it:

While the cooperation between the peoples of Europe is limited to a reduced number of multilingual people in each country, all social strata, thanks to the similarities between the Danish, Norwegian and Swedish languages, are part of the Nordic cooperation. ${ }^{40}$

Still this was not something that could be taken for granted in the daily life of the school. Many of the students had never been abroad and lacked experience in interScandinavian communication. In a letter from the first year's course, a Swedish participant commented that the language situation had been mostly unproblematic, but made a reservation concerning the Danes. ${ }^{41}$ Reports from the rector and teachers were more concerned, underlining how it was of utmost importance that the students spent much time on "the practical study of the Scandinavian languages," including daily reading of newspapers from all the three countries. ${ }^{42}$ From 1935 an introductory course in the differences between Danish, Norwegian and Swedish was introduced at the beginning of the school programme. A most welcome one, according to student Ingrid Berg, warning in Arbeiderbladet that although reading texts in all three languages was easy, face to face communication was quite a different matter.

[E]very now and then one feels disoriented [...], looks a bit surprised at the other, who looks back in the same way, and in the end we nod good-heartedly but without confidence at each other and say $j a$ and $h a$-the misunderstanding is a fact, because we didn't fully understand what the words meant. ${ }^{43}$

Courses and practice represented the best cure, according to another participant, claiming that classes in the different languages was hard in the beginning, although soon enough that stage was bypassed. "It is amazing how quickly one acquires the entirely necessary routine of mutilating different languages," wrote another one, pointing to how the Scandinavian students ended up by mixing the three languages in their communication. ${ }^{45}$

40 "Bedre vilkår for mellemfolkelig samarbeide i NORDEN enn mellem noen andre nasjoner," 1ste Mai, May 19, 1936.

41 Karl Nilsson, "Kring Genèveskolan," Mellanfolkligt samarbete 7, November 1931, 271.

42 Axel Sömme, "Beretning om undervisningen ved Nordisk folkehøiskoles 4de kursus i Genève april-mai-juni 1934," report dated July 17, 1934, vol. 38, Föreningen Nordisk Folkhögskola i Genève (NFG), ARAB, 6. See also Finn T. B. Friis, Axel Sømme, "Forslag til Retningslinjer for Undervisningen ved Nordisk Folkehøjskole i Geneve," letter dated August 19, 1934, vol. 1, FNG, ARAB.

43 Ingrid Berg, "Geneveskolen—et utmerket tiltak," Arbeiderbladet, October 8, 1935.

44 Arne Mellesmo, "Med Nordiske Folkehøgskole til Geneve," Dagningen, June 30, 1939.

45 Hans Sandås, “Geneve- 'Verdens hovedstad:' Litt om arbeidsbyrået og dets virksomhet,” Sarpsborg Arbeiderblad, 24 July, 1939. 
The introduction of a pre-course at a folk high school in Scandinavia provided both common ground and comradeship before the trip to Geneva began. If the introduction to the Scandinavian language community represented one stage of the Nordic folk high school's course in internationalism in practice, another important social aspect of the school was the travels. Foreign travel was still a privilege of the few during the interwar period. ${ }^{46}$ In the mid-1930s things started to change, following the introduction of vacation laws in some countries, spurred on by the adoption of a convention at the International Labour Conference in 1936, and the following year Swedish ABF founded its own travel agency, Reso. ${ }^{47}$ Among the organisers of the Geneva School, there was a strong belief in the pedagogical potential in travelling for the students, in "seeing rather than reading." 48 Here, too, the democratising ambitions of the school were evident: it was common for the students to stress that this was their first-and possibly last — trip abroad, at least outside the borders of Norden. ${ }^{49}$

Between Scandinavia and Geneva, the school was on the move inside a political-cultural geography that made use of the expanding networks of modern transport, from continental sleepers and intercity express trains to buses on the Autobahn and North Sea steamers. Historians have pointed out how the internationalisation of transport greatly improved the opportunities for intensive exchange across borders in the interwar years. ${ }^{50}$ The speedy and impressionistic experience of modern travel was described in the following way by a student in 1937, on the way from Esbjerg towards Geneva:

\begin{abstract}
A wonderful day on the North Sea onboard the steamer A.P. Bernstorff-with the speed of lightning from Antwerp to Brussels [...] and we find ourselves as veritable tourists in one of Europe's great capitals. The Belgian King's two castles, the church in Laken $[\ldots]$, hat off at the tomb of the unknown soldier, the Palace of Justice [...], parcs and poor quarters, and goodbye to Belgium. ${ }^{51}$
\end{abstract}

Leppänen suggests that the study trips of the school followed in the footsteps of the nineteenth century German bildungsreisen. This was certainly true, although the travels also clearly included elements of modern tourism's checklist of sights to see. By and large, however, the stops of the trips were dedicated to the discovery of social progress and innovation, such as visits to the Zuiderseedamm in the Netherlands, tours of consumers' cooperatives in England, and inspections of the Reich Labour Service (Reicharbeitsdienst) in Germany. The school thus represented an adventurous voyage for the participants, but also an educational one, where the foreign conditions, ranging from industrial achievements to miserable housing conditions, were constantly compared to the situation back home.

46 Klas Grinell, Att sälja världen: Omvärldsbilder i svensk utlandsturism (Göteborg: Acta Universitatis Gothoburgensis, 2004), 124.

47 Carina Gråbacke, När folket tog semester: Studier av Reso, 1937-77 (Lund: Sekel, 2008), 40.

48 Leppänen (2011), 640.

49 Arne Mellesmo, “Med Nordiske Folkehøgskole til Geneve," Dagningen, June 30, 1939.

50 Reijnen and Rensen (2014), 20.

51 B. B., "Tvers gjennem Europa: Med Nordisk folkehøiskole til Geneve," Bergens Tidende, July 10, 1937. 
To put aside the daily work in known surroundings in a remote fjord village home at Vestlandet and suddenly find oneself in the midst of the centre of Europe, yes, even the world-seems somewhat shocking. But when one gets used to the new light unknown perspectives open up..$^{52}$

The boarding school experience, administered by a Scandinavian "husmor," ${ }^{53}$ represented a refuge from the cacophony of the international capital; although the students did get a taste of what Glenda Sluga calls "a Genevan culture of conferencing and local tourism - a kind of education in cultural difference and exchange,",54 their daily communal evening meal was grøt (porridge). ${ }^{55}$ The magnificence of the city of Geneva and its surroundings represented a wide range of things, alongside the inevitable international institutions. An encounter with "French" culture for some students. An introduction to Alpine landscapes for others. But above all, it was the "centre of the world," 56 which offered a glimpse into the unknown stages and corridors of contemporary international affairs. ${ }^{57}$ During the weeks in Geneva, general courses were taught by the school's permanent teachers, while experts from the League or the ILO lectured on their topics of expertise. Most of these teachers were Scandinavian officials, but the list of external lecturers also included central figures in Geneva such as ILO director Harold Butler, who was translated by Backlund.

Among the institutions precisely the ILO held a particular position for the Geneva school, which coincided with the annual International Labour Conference so that the students could attend.

To sit on the press gallery during the International Labour Conference and look at the representatives of the most different of races [...] assembled in the meeting hall, is a very interesting study, and gives one international perspectives, even though one is less impressed by what's going on during the negotiations themselves. ${ }^{58}$

This participation was made possible by two things. Backlund's contacts at the ILO provided the Nordic folk high school students with press passes that gave access to the conference, and the introduction in the late 1920s of headphones for simultaneous

52 Bjørklund, (14 July, 1937).

53 Gabrielle 'Gabbi' Sømme (1899-1952) was married to Axel Sømme, rector of the school from 19331935, but continued to work for the Geneva School as well as for Desjardins in Pontigny throughout the 1930s.

54 Glenda Sluga, Internationalism in the Age of Nationalism (University of Pennsylvania Press: Philadelphia, 2013), 74.

55 Axel Sömme, "Beretning om undervisningen ved Nordisk folkehøiskoles 4de kursus i Genève april-mai-juni 1934," July 17, 1934, 1. A course participant from Stavanger recounts in a letter his amazement upon attending "Consul Bakke's fish dinner," a fixed point on the annual programme, where the Norwegian consul had served angler quenelles - in fine company one shockingly saw fit to present the guests with the sort of undesired fish that back home was always thrown back in the sea. See O-l, "Inntrykk—overraskelser—oplevelser: Reisebrev fra Geneve," 1ste Mai, June 28, 1935.

56 Mellesmo, (June 30, 1939).

57 Benjamin Bjørklund, "Ferdabrev: Gjenom Danmark, Nederland og Tyskland til Sveits: Og 6 vikors upphald i Geneve," Firda folkeblad, July 20, 1937.

58 O-l., "I problemene og motsetningenes verdenssentrum. Reisebrev fra Geneve," 1ste Mai, June 22, 1935. 
translation of the speakers made it possible also for non-French or English-speakers to follow the deliberations. The technology impressed the students, ${ }^{59}$ although the most impressive feat for one young social democrat was Backlund's translation skills. They assured that when Labour MP Helga Karlsen came as a delegate she could make her speech to the conference about the forty-hour week in "genuine Oslo vernacular" and still receive great acclaim. "It was [Backlund] who stood by Helga's side when she spoke.- 'And then I felt just as safe as if I were standing back home in Norway', she told us down here afterwards." ${ }^{30}$ Pauli Kettunen has highlighted how the month-long conferences through their regularity and length represented important arenas of socialisation and informal communication across the three groups of employers, unionists and government representatives that constituted the tripartite structure, including for interaction on the national level. ${ }^{61}$ They were also occasions for interaction between the students and the Scandinavian delegates, for example at "Nordic dinner parties" arranged in Genevan summer evenings where all delegates, together with diplomats and officials from the institutions were present. All this contributed to make the students come back to Scandinavia with insight in the workings of the institutions and full of Nordic experiences. Many students carried on the torch by writing in newspapers and periodicals, making public talks for local educational associations, and some also launched initiatives such as annual Nordic study weeks, which made use of the folk high school networks and often could boast lecturers representing both the political and academic elite. Some students were inspired to take part in other internationalist programmes, like the Swede Karl Ekblom. Rich on the experience from the Nordic folk high school, he regretted how "remarkably" removed other Genevan summer schools seemed to be from the "peace efforts of the labour movement and the social injustices in the world," suggesting how this was a natural reflection of the social composition of participants in such initiatives. ${ }^{62}$ In this respect, he contended, the Scandinavians were truly pioneers.

The students' practical introduction to international life followed a fixed path. They first met the Nordic language community in the pre-school programmes organised at folk high schools in southern Scandinavia. The school itself was no permanent place, taught as it was in a combination of correspondence courses, study circles, lectures, field trips, and study visits. More precisely, it operated as a temporary travelling party around Europe, with only two fixed points on its map, Geneva and Pontigny. On the way to Switzerland the students met Continent's ports, landscapes, towns and rivers. After intensive study weeks at the institutions the school relocated to Pontigny for a quieter atmosphere of study, to digest impressions before the trip home. In a sense, the school's structure was built around a logic were the students first became Nordists before they could become internationalists; this was both a linguistic and spatial lesson.

59 Sandås, (July 24, 1939).

60 O-l., (June 22, 1935).

61 Pauli Kettunen, "The ILO as a Forum for Developing and Demonstrating a Nordic Model," in Globalizing Social Rights. The International Labour Organization and Beyond, ed. Sandrine Kott and Joëlle Droux (London: Palgrave Macmillan, 2013), 213-14.

62 Karl Ekblom, "Uppfostran till en internationell värld," Mellanfolkligt samarbete 7, 1934, 267-68. 


\section{A school for Europe's democratic youth}

The end of what Zara Steiner calls "the hinge years," with the Nazi seizure of power and following withdrawal of Germany from the League along with the spread of economic crisis in continental Europe changed European political geography. ${ }^{63}$ In this new political map of Europe, new centres emerged, linked by their democratic systems: England, France, the Benelux, the Nordic countries, Czechoslovakia. It was no coincidence if a book written by the French journalist and activist Pierre Paraf published in 1935 bore the title Clartés d'Europe; the Frenchman visited and compared the Third Republic to the Czech "republic of philosophers" and the Scandinavian "lands where liberty is preserved." ${ }^{4}$ While Paraf was soon followed by other continental observers interested in studying at close hand the evolution of the Nordic democracies, the European situation also led the Nordic folk high school more directly into contact with new milieus on the Continent. ${ }^{65}$ "As the decade dragged on," writes Sluga, "the League of Nations was less and less at the center of influential internationalist initiatives." ${ }^{66}$ With the failure of the League, new arenas for internationalism appeared across democratic Europe.

One such arena was Paul Desjardins' Pontigny. The French philosopher had at the beginning of the century bought a medieval Cistercian abbey in Burgundy, where he created the Décades de Pontigny - ten-day seminars for European intellectuals that made it a key site for transnational exchange. From the mid-1930s, Pontigny's activities took a marked political and social turn, in "defence of a humanism under threat" in the words of historian François Chaubet. ${ }^{67}$ The repercussions of the economic crisis, the German aggressions, and the fascist threat in France all contributed to constitute what Chaubet describes as a Damascene moment for Desjardins. The abbey thus became a meeting place for European socialists, housing importantly the First and Third International Plan Conferences in 1934 and 1937, where a range of leading European theoreticians assembled to discuss Hendrik de Man's ideas about planism. ${ }^{68}$ Following Desjardin's turn towards the workers' organisations, other international activities came to be organised at Pontigny, e.g. the summer courses of the Amsterdam International, as well as workers' study weeks organised by the French General Confederation of Labour (CGT).

In 1935 Backlund encountered Desjardins, and starting that year the Geneva school's programme included complementary study weeks there. The abbey was renowned for its library and study facilities, and they were put to use for the school's

63 Zara Steiner, The Lights that Failed: European International History 1919-1933, Oxford University Press: Oxford, 2005.

64 Pierre Paraf, Clartés d'Europe, Paris: Editions R.-A. Corrêa, 1935.

65 On the Continental travelogues from Norden in the 1930s see Peter Stadius, "Happy Countries: Appraisals of Interwar Nordic Societies," in Communicating the North: Media Structures and Images in the Making of the Nordic Region, ed. Jonas Harvard and Peter Stadius (London: Routledge, 2013).

66 Sluga (2013), 76.

67 François Chaubet, Paul Desjardins et les Décades de Pontigny (Paris: Presses universitaires du Septentrion, 2000), 203. The Scandinavian connections are ignored by Chaubet.

68 See Gerd-Rainer Horn, “From 'Radical' to 'Realist:' Hendrik de Man and the International Plan Conferences at Pontigny and Geneva, 1934-1937," Contemporary European History 10, no. 2 (2001), 239-65; see also Tommaso Milani's thesis "Les Belles Années du Plan?" Hendrik de Man and the Reinvention of Western European Socialism, 1914-36 ca. (PhD diss., London School of Economics and Political Science, 2018), 175-78. 
lectures and seminars. ${ }^{69}$ In 1937, to give an example from the curriculum, rector Sigurd Juul Andersen taught a class on the transformations of the home and society in the context of technological change and rationalisation, Degerman and Backlund finished courses about the 23d Labour Conference, and Ording lectured about French history from the revolution to the Popular Front. ${ }^{70}$ While the days were spent with books, the evenings at Pontigny offered a refined cultural programme, with literature and poetry readings by visiting French writers, as well as French and Nordic song, music and discussions. A student writing back from Pontigny observed that "if the spirits of any of the old abbots hover through the rooms they would undoubtedly be surprised and horrified by modern monastic life." 71

There were two central aspects of the Scandinavian developments that in particular fascinated Desjardins: the role of popular education through the folk high school movement, and the creation of worker-farmer alliances to counter fascism and fight the economic crisis. Although slightly varying from country to country, these cross-party agreements ensured that social democrats got support for welfare reforms by agreeing to introduce agricultural subsidies to fight the slump on the countryside. ${ }^{72}$ Their shared interest in the combination of internationalism, education and peace struggles made Backlund and Desjardins conceive another FrenchScandinavian initiative, the meeting between "an old nation" and "the bastions of liberty in the North." ${ }^{\prime 3}$ The vision of creating a new meeting place for young people from France, Scandinavia and other democracies sought to unite two ideas, as Desjardins wrote, "on the one hand take part in the work of restoring a tattered Europe, on the other to create the transnational school that his Swedish friend dreamed of." 74 The Amitié enseignante de Pontigny or Anti-Babel would by Backlund be introduced in Scandinavia as "studiekamraterna i Pontigny," and its programme that of "education through comradeship." 75 He presented it as an initiative that drew on the heritage of the folk high schools and the workers' educational associations, and these movements were mobilised to find suitable candidates. In Oslo, it caught the attention of the Department for Romance languages and literature through the philologist Gunnar Høst, engaged as one of the teachers of the Anti-Babel. Observing that this new study course represented opportunities which were "something different than staying at a boarding house and talk to Americans," the professors started to send their students to Pontigny. ${ }^{76}$ And similar to the Geneva school's possibilities to make use of the abbey's facilities and cultural activities, the Anti-Babel students were offered a varied programme. The idea was that the students from different countries

69 "Nordisk Folkehøiskole i Genève. Dec. 1937," protocol from board meeting in Stockholm, December 18-19 1937, vol. 1, NFG, ARAB, 2.

70 Ibid.

71 Benjamin Bjørklund, “Moderne klosterliv: Nordisk folkehøiskole i Frankrike," Bergens Tidende, August 7, 1937.

72 Hilson, Neunsinger, Vyff and Kristjánsdóttir (2017), 16.

73 Quoted in Sven Backlund, På jakt efter Europa (Stockholm: Kooperativa förbundets bokförlag, 1952), 119-20.

74 Quoted in Backlund (1952), 125.

75 Sven Backlund, "Pontigny," undated manuscript, series 3, vol. 1, Manuskript(samling) (MS), ARAB, 2.

76 Magne Skodvin, "Paul Desjardins og nordmennene i Pontigny," in Fransk i Norge, ed. Anna-Lisa Amadou et al (Oslo: Aschehoug, 1975), 146-47. 
met up in Pontigny to study Europe's problems against the background of local studies of the region's ancient French villages, rich in historical remnants from Romans. The study of contemporary issues included both agricultural facilities in Burgundy and trips to study modern industry in Paris. ${ }^{77}$ Moreover, the trips to Paris included visits to Desjardin's debating society L'Union pour la Verité. ${ }^{78}$

Through Backlund and Desjardins' collaboration, Pontigny was put on the map of Scandinavian intellectual milieus. During these years of mounting threats against democracy, it continued to represent a form of liberalism revivified by a modern humanist socialism, and was a source of inspiration for one of the period's most ambitious Scandinavian educational projects, the creation of the Norwegian humanistic academy Nansenskolen in 1938. In France Pontigny's activities were part of a sort of renovation of democracy, from theoretical debates on political philosophy to the practical task of helping refugees. The Scandinavian students finding themselves in the midst of all this took an active role in establishing the abbey as a centre for regional coordinating efforts to receive political refugees, notably from Nazi Germany, the Spanish Republic and the International Brigades. ${ }^{79}$ The Norwegian student Hans Sandås wrote back about how the encounter with refugees was a deeply unsettling experience: "We've all read the newspapers' depictions of all the horrendous things that these poor people have gone through. We all pity them, of course; but most of us probably don't reflect that deeply about what we hear and read." ${ }^{80}$ Meeting women and children, some of them orphans, who had fled fascism was an entirely different thing, and made him wonder, despite all criticism against the League of Nations, what Europe would have looked like without it: "how many refugee camps would we then have seen today?"81

Pontigny's opening to the democratic youth of Scandinavia took place within a French context where several groups sought information and cooperation with the Nordic social democracies. ${ }^{82}$ At the Paris International Exposition of 1937 the Nordic pavilions were praised in the French centre-left press for their uncompromising democratic positions, presenting progressive counter-images to the monumentalism of the Soviet and German pavilions. The popularity of the Scandinavian pavilions marked the point of departure for an article series from Scandinavia written by the journalist Jules M. Guesde, the half-Norwegian grandson of the socialist leader Jules Guesde. Government mouthpiece Le Populaire introduced Guesde's articles as a direct follow-up to coverage of the Exposition, seeking to inform readers in detail about the Scandinavian social realisations. ${ }^{83}$ According to the socialist Georges Lefranc, the

77 Backlund, "Pontigny," MS, ARAB, 2.

78 Skodvin (1975), 144.

79 One of these refugees was the German communist Charlotte von Steinbock-Fermor, whom Gabbi Sømme managed to help to Norway in 1939. In Pontigny she met Einar Hirdman, a student at one of the courses taught there. The two later married. This story is told by Yvonne Hirdman in her book Den röda grevinnan: En europeisk historia (Stockholm: Ordfront, 2010).

80 Hans Sandås, "Små sluttbemerkninger om Folkehøiskolen i Genève, og litt om de spanske flyktninger," Sarpsborg Arbeiderblad, August 15, 1939.

81 Ibid.

82 On the French interest for Sweden in the mid-1930s see Andreas Mørkved Hellenes, Fabricating Sweden. Studies of Swedish public diplomacy in France from the 1930s to the 1990s (PhD diss., Sciences Po Paris \& University of Oslo, 2019), 49-80.

83 Jules Guesde, "Voyage en pays scandinaves: Au libre et démocratique Danemark," Le Populaire, October 11, 1937. A number of appreciative articles by Guesde were published from Denmark, Sweden and Norway over the following weeks. 
pavilions had led many French socialists to discover the countries and their achievements. ${ }^{84}$ The historian Lefranc, a regular visitor to Pontigny, had a few years earlier been one of the instigators of the CGT's Institut ouvrier supérieur (Workers' institute for higher studies) and ran together with his wife Émilie Lefranc the Centre conféderal d'éducation ouvrière (CCEO), both of them institutions that grew rapidly with the support of the Popular Front government. Through Backlund, Lefranc got in contact with the Scandinavian counterparts to his French initiative, namely the workers' educational associations. In 1938, Lefranc organised the study trip "La vie scandinave" (Scandinavian life) for students of the CCEO to Denmark and Sweden, spending among other things a week as guests at the ABF's school in Brunnsvik and visiting $\mathrm{KF}$ and LO in Stockholm. ${ }^{85}$ Backlund again served as an intermediary between Nordic and continental milieus the following year, in the most mediatised episode of French interest in Scandinavian solutions to contemporary challenges during the decade, the so-called French-Swedish meeting in Pontigny.

In search for social peace: French questions and Swedish answers in the abbey French historian Olivier Dard has shown how during the late interwar years important groups of intellectuals and experts in France were orientated towards foreign countries, traveling to confront their ideas to those of others and observed the foreign experiences sometimes considered models to follow, either finding inspiration in or rejecting them. ${ }^{86}$ Many were graduates of the École polytéchnique, and gravitated around recently created institutions for economic policies, groups like $X$-Crise and magazines such as the Nouveaux Cahiers, in overlapping networks of reformist trade unionists and reform-minded industrialists and public administrators sharing a strong belief in how technocratic policymaking could establish mechanisms to keep peace. A key concern was to find out how-after the massive strikes and eventual political failure of the Popular Front experience in 1937-38-one could find a "third way" to rejuvenate democracy in order to face the perils of fascism and communism, not least by introducing "industrial" or "social" peace. "Social peace," the Nouveaux Cahiers' leading figure Auguste Detoeuf wrote not long after the fall of the Popular Front, citing the evolution in Scandinavia, was the best way to assure "social progress." One of his close collaborators, the engineer Paul Planus, went to Sweden and wrote a study of labour relations and the Swedish way to social peace. ${ }^{87}$ On Backlund's initiative and with Desjardins' approval, the Nouveaux Cahiers invited the leadership of LO and their counterparts in the SAF to a three-day seminar at Pontigny in June 1938.

In a letter to the LO, Detoeuf stated that he had read about the "state of social relations in Sweden" and concluded that it would be highly desirable for France to go through a similar development. ${ }^{88} \mathrm{He}$ therefore wanted Swedish representatives

\footnotetext{
84 Georges Lefranc, preface to Visite aux Ouvriers Scandinaves, by Georges Albertini (Paris: Conférences de l'Institut supérieur ouvrier, 1938), 3.

85 The CCEO aired radio lectures about social Sweden and published a more general introduction to Scandinavia written by one of the participants, see Albertini (1938).

86 Olivier Dard, Le rendez-vous manqué des années 30 (Paris: Presses Universitaires de France, 2002 ), 8. 87 Paul Planus, Patrons et ouvriers en Suède: vers la paix sociale (Paris: Plon, 1938).

88 From Nouveaux Cahiers to LO, letter dated March 31 1938, series E9A, vol. 21, LO, ARAB, 1.
} 
to come to France to "show by their declarations and their examples the methods used in Sweden." ${ }^{89}$ In other words, the main object of the seminar was to present to French industrialists and trade unionists the systematic negotiations between the two parties on the labour market conducted at Saltsjöbaden. In France, the Nouveaux Cahiers, together with Backlund and the French-Swedish businessman Rolf Nordling, prepared the meeting. Nordling made it clear to the Swedish invitees that the French did not want to make any presentations, considering that they had little to teach the Swedes on the matter in question while conversely having almost everything to learn from them..$^{90}$ In Sweden, SAF and LO produced a compendium defining seven different domains of particular interest within the Swedish developments. This became the basis of the Pontigny meeting and would later be published in its entirety by the Nouveaux Cahiers. In seven sessions chaired by Nordling, the Swedes presented their exposés with Backlund translating. Each exposé was followed by long debates where the French participants posed questions to the Swedes. Despite the participants' insistence that the event was no more than an "information meeting," it provoked a violent debate in French newspapers over the relationship between trade unions and employers, not the least as some of the participating syndicalists hinted at supporting a "Scandinavisation" of the French labour market. ${ }^{91}$ Detoeuf, in his closing speech, did not hesitate to identify in the road to social peace a mechanism to safeguard European democracy:

Swedes and Frenchmen, we both need to save our threatened democracies; we need to save all that can be saved of our liberties, all that can be saved of our old and noble civilisation [...]. It is an immense service [...] that our Swedish friends have given us in this Abbey of Pontigny, one of the spiritual centres of a Europe that will not die. ${ }^{92}$

Meanwhile, in Sweden, the event above all seems to have generated increased understanding for the national importance of the Saltsjöbaden negotiations. Social democratic and bourgeois newspapers alike wrote enthusiastically about the great interest in France for Swedish solutions, and the sentiment spread over the western border. ${ }^{93}$ Norwegian labour daily Arbeiderbladet, characterising the Swedish delegation as "Nordic missionaries," stated that they had brought sanity to a country in dire need for some. ${ }^{94}$ The strength of the encounter as opposed to the regular press reports was that it provided a very concrete stage for a performance of cooperation. Similar to how the Geneva school had been "open for all" and staged discussions between

89 Ibid.

90 From Nordling to Lindbergh (sic), letter dated May 31 1938, E9A, vol. 21, LO, ARAB.

91 C.-A. Bolander, "Svensk anda triumferar. Samförstånd och kamratlighet i Pontigny," Dagens Nyheter, June 27, 1938.

92 “Discours de M. Detoeuf au déjeuner de clôture du Congrès de Pontigny”, speech dated June 291938 , series F51H, vol. 4, Svenska arbetsgivareföreningens arkiv (SAF), Centre for Business History (CBH), 6.

93 C.-A. Bolander, "Svensk-fransk arbetardebatt. Ett Sigtuna i Pontigny," Dagens Nyheter, June 26, 1938; H. H-th., "Franska frågor i mängd vid Pontignymötet," Svenska Dagbladet, June 28, 1938; "Pontigny gav impulser till fortsatt samarbete i Frankrike," Arbetet, July 4, 1938; "Ny världsartikel?" Metallarbetaren, July 6, 1938; “Frankrike studerar svenska arbetsförhållanden,” Aftonbladet, July 13, 1938.

94 Tor Gjesdal, “Nordiske 'misjonærer' lærer Frankrike folkeskikk i arbeidslivet,” Arbeiderbladet, July 9, 1938. 
students of different social classes and sometimes political convictions, the SAF and LO leaders participating in Pontigny drove home their message all the stronger as a result of their performance of the spirit of compromise - what Dagens Nyheter's Paris correspondent called "the spirit of Saltsjöbaden." 95 This was not only true for the presentations and question-and-answer sessions in the abbey, but also highly present-and noticed by the French-outside of the discussion rooms. One episode in particular was singled out in many reviews. On the last evening of the meeting, participants celebrated at a restaurant in the neighbouring village of Vézelay. The dinner ended with the Swedish guests, LO and SAF men alike, performing sailor songs arm-in-arm. In a way, it staged an anecdote popular in French contemporary writings from Scandinavia, attributed to Lenin:

\footnotetext{
If, Lenin declared after having passed through Stockholm, a coup détat ever was to occur in Sweden, the revolutionary government would start by hosting a dinner for the bourgeois government it had overthrown [...]. And the capitalists would hasten to return the courtesy. ${ }^{96}$
}

The episode reverberated in the press, with those positive to the meeting identifying this as a truly extraordinary example of the spirit of class-transcending compromise and cooperation in Sweden. ${ }^{97}$ Conversely, Communist and anarchist press described it in terms of class treason..$^{98}$ The image of industrial leaders and workers' representatives toasting happily confirmed, for those positive, the advanced character of social and labour relations in Sweden, while the critics saw this sort of fraternisation as precisely the evidence of the limits of social democratic reformism.

\section{Conclusion: Internationalising the Scandinavian experience}

The Pontigny episode marked the peak of the French interest for Scandinavian social democracy in the interwar period. It should be interpreted in the context of the late 1930's many transnational encounters where intellectuals and practitioners of different strands met to discuss ideological renewal to overcome the stalemate of the European liberal democracies, from the Plan conferences to the Colloque Walter Lippmann. By collecting and disseminating up-to-date information about Swedish social and labour market politics as well as generating a number of French reports, the French-Swedish meeting functioned as a workshop that produced not only knowledge about the Swedish solutions to the contemporary crisis in Europe, but also the myth of a reformist paradise in Scandinavia. Importantly, it was made possible by politico-intellectual networks that believed strongly in international ex-

95 C.-A. Bolander, "Svensk anda triumferar. Samförstånd och kamratlighet i Pontigny," Dagens Nyheter, June 27,1938 . This is the first occurrence of this term, which during the post-war era would become a central part of both Swedish self-images and frequently referred to in foreign portrayals of the country, that is recorded in Kungliga biblioteket's digitised newspaper collections.

96 Serge de Chessin, Les Clefs de la Suède (Paris: Hachette, 1935), 67.

97 See for example Raymond Millet, "La leçon que nous ont apportée syndicalistes et patrons suédois," Le Temps, June 20, 1938; Pierre Bost, "Sous les ombrages de Pontigny M. Jouhaux et M. Gignoux parlaient bien amicalement...," Paris-Soir, July 5, 1938.

98 Gustave Rodrigues, "Pontigny, centre de trahison ouvrière," Nouvel Age, July 4, 1938; Georges Valois, "La charte d'Amiens déchirée," Nouvel Age, July 5, 1938; Gaston Bergery, "Scandale à Pontigny," La Flèche, July 8, 1938. 
change to tackle the menace posed by communism and fascism. In this mix, education had a particular position. Not in the stricter sense of curricula and organised scholarship, but the ambition of learning from shared experiences, and bringing together both the democratic youth and technocratic experts from different social and national backgrounds facing shared problems. It was Desjardins' interest in Nordic popular education and Backlund's capacity to serve as an intermediary between the French and Nordic spheres that brought the Geneva school to Pontigny in the first place, thus establishing it as a site of reference for Scandinavians and making possible the organisation of the meeting. Moreover, Pontigny-as well as Brunnsvik and other workers' folk high schools across Scandinavia-offered possibilities for the individuals and groups involved to create veritable border-crossing encounters.

By bringing out the internationalism of the workers' educational associations, this article has added another layer of understanding to the late interwar period's foreign interest in the Nordic region. This suggests that, in order to identify important moments of transnational contact, it is necessary to look beyond the bilateral relations of party organisations or the works of literary travellers; they were just as much or more a result of the creation of other connections. Moreover, the article has identified political and cultural intermediaries who were not diplomats, and whose international cultural relations were not concerted cultural diplomacy. ${ }^{99}$ Perhaps their activities could be seen as a form of transnational democratic activismwhose activities inadvertently yet all the same contributed to increase the reputation of the Nordic region. The "Genevese-Pontagnacian construction of Norden" analysed here thus differs from the Genevese construction analysed by Götz as well as Gram-Skjoldager, Ikonomou and Kahlert, and notably in its shape as a way to social peace and as a democratic stronghold whose experiences could inform the French debates over the future of democracy and capitalism. In this way the example of the Pontigny meeting illustrates the periphery's capacity to achieve "shortcuts to modernity" before the centre. ${ }^{100}$ The case reveals an interesting dynamic in this process between culture and politics. While the Nordic students in Pontigny readily accepted their position as "pilgrims" to an ancient site of European culture, the Swedish trade unionists and employers got assigned the role of "Nordic missionaries." Similarly, the unstable relationship between cultural centre and periphery reveals itself in the altering press portrayals of the Pontigny meeting, as they shift between depicting the Swedes as either teachers giving lessons or as students under examination. The Pontigny episode can in this way be characterised as a socio-political example of what Pascale Casanova in her studies of world literature has referred to as "consecration," namely the elevation of the cultural periphery's innovations by the centre. ${ }^{101}$ To be sure, in France the meeting contributed heavily to establish the reference to Swedish labour market solutions in particular and to Swedish reformism in general in the catalogue of political tropes. This opens an interesting path that cannot be explored

99 For a study of a similar dynamic in contemporary official Swedish-international cultural relations see Nikolas Glover and Andreas Mørkved Hellenes, "A 'Swedish Offensive' at the World's Fairs: Advertising, Social Reformism and the Roots of Official Swedish Cultural Diplomacy, 1935-1939," Contemporary European History (fc., 2020).

100 Stefan Nygård and Johan Strang, "Facing Asymmetry: Nordic Intellectuals and Center-Periphery Dynamics in European Cultural Space," Journal of the History of Ideas 77, no. 1, January (2016), 96.

101 Pascale Casanova, La république mondiale des lettres (Paris: Seuil, 1999), 47-61. 
here, namely of the impact that meeting had not on French developments, but on the Swedish participants and their ongoing negotiations six months before the Saltsjöbaden deal was sealed. It also raises a question that falls outside of the scope of this article, namely of the effects that the encounter with Geneva and Pontigny had on the some three hundred "Nordic" students that attended the school in the 1930s and their careers before, across and beyond the world war. ${ }^{102}$

The examination of the Geneva school's internationalism as praxis has offered three avenues to the study of socio-spatial transnationalism in Europe during the late interwar period. First the temporary, travelling school's movements makes it possible to trace a contourless cultural-political map of Europe hachured by contemporary social themes and connected to only a few fixed points: Pontigny, Geneva, and a limited number of folk high schools in Scandinavia. In turn this has allowed for an expansion into the social history of Scandinavian internationalism, by enlarging the scope from diplomats and decision-makers to the popular movements, notably the workers' educational associations, the folk high school teachers and students-several of whom later became influential actors in other social spheres. Secondly, this has shown that the Geneva school mobilised Nordism as a cultural strategy to produce a specific Scandinavian and social democratic internationalism, both by observing "international questions" through the optics of "new Nordism," and perhaps just as importantly by educating students through travels, readings and teachings in the Scandinavian languages. The students' discovery of the world centre of Geneva and the heart of European culture at Pontigny was in this way also an encounter with Nordic cooperation as lived reality, and in the extension of this a re-discovery of the fatherland. Their shared experiences of these entangled sites made them Nordistsand internationalists. Thirdly, the study of the school reveals the many entanglements and overlaps both between different transnational groups and activities. If an ambition of the school's operations was the creation of Nordic internationalism, an effect was to internationalise the Scandinavian experience, in the sense of defending democracy against dictatorship by means of first the alliance between the workers of the countryside and the cities and secondly the establishment of social peace.

\section{Acknowledgements}

I am grateful to my project colleagues Mary Hilson, Carl Marklund and Byron RomJensen as well as to Nikolas Glover for their valuable comments which have improved the article. Earlier drafts have been presented at the research seminar of the Institute for Contemporary History, Södertörn University in 2018; the Nordic Challenges Conference in Copenhagen and at the workshop "International Interactions-Images and Imaginations-Education in the Nordic Countries between the Nation State and the Competition State" in 2019. I am grateful for the input I received at these occasions. 


\section{References}

\section{Archival sources}

Swedish Labour Movement's Archives and Library, Flemingsberg (ARAB)

Föreningen Nordisk Folkhögskola i Genève (NFG)

Protokoll, 1

Verksamhets- och revisionsberättelser och stadgar, 2

Rektorsrapporter, 38

Landsorganisationens arkiv (LO)

Internationell korrespondens, länder, E9A:14; 21, Tidningsklipp, Ö1:294

Manuskript (samling) (MS)

Övriga manuskript (politiska och andra artiklar, tal m.m.), 3:1.

Centre for Business History, Bromma

Svenska Arbetsgivareföreningens arkiv (SAF)

F47 (oförtecknad serie), "Pontigny-konferensen"

Direktör Gustaf Söderlunds handlingar (GS), F51 A:1

Wiking Johnssons handlingar (WJ), F51H:4

Bibliothèque d'histoire sociale La Souvarine, Nanterre (BHS)

Fonds Georges et Émilie Lefranc (GEL)

Fonds George Lefranc

"Rencontres franco-suédoises 25, 26, 27 1938"

Published sources

Aaraas, Hans. "Gjensyn med Pontigny." In Vi valgte fransk: Fransk på norsk grunn, edited by Asbjørn Aarnes \& Magne Skodvin, 100-12. Oslo: Universitetsforlaget, 1986.

Backlund, Sven. "Skola i Genève." Mellanfolkligt samarbete, April, 1931.

Backlund, Sven, Axel Sømme and Arne Sørensen. Den største høittaler og fem andre aktuelle problemer. Oslo: Tiden, 1933.

Backlund, Sven. På jakt efter Europa. Stockholm: Kooperativa förbundets bokförlag, 1952.

"Bedre vilkår for mellemfolkelig samarbeide i NORDEN enn mellem noen andre nasjoner." 1ste Mai, May 19, 1936.

Berg, Ingrid. "Geneveskolen—et utmerket tiltak." Arbeiderbladet, October 8, 1935.

Bergery, Gaston. "Scandale à Pontigny." La Flèche, July 8, 1938.

Bjørklund, Benjamin, "Tvers gjennem Europa. Med Nordisk folkehøiskole til Geneve." Bergens Tidende, July 10, 1937.

Bjørklund, Benjamin. "Seks sommer-uker ved Geneve-sjøen." Bergens Tidende, July 14, 1937.

Bjørklund, Benjamin. "Ferdabrev: Gjenom Danmark, Nederland og Tyskland til Sveits: Og 6 vikors upphald i Geneve." Firda folkeblad, July 20, 1937. 
Bjørklund, Benjamin. “Moderne klosterliv: Nordisk folkehøiskole i Frankrike." Bergens Tidende, August 7, 1937.

Bjørklund, Benjamin. "Med nordisk folkehøgskule i Frankrik (sic).” Firda folkeblad, September 17, 1937.

Bolander, C.-A. "Svensk-fransk arbetardebatt. Ett Sigtuna i Pontigny." Dagens Nyheter, June 26, 1938.

Bolander, C.-A. "Svensk anda triumferar. Samförstånd och kamratlighet i Pontigny." Dagens Nyheter, June 27, 1938.

Bost, Pierre. "Sous les ombrages de Pontigny M. Jouhaux et M. Gignoux parlaient bien amicalement..." Paris-Soir, July 5, 1938.

Chessin, Serge de. Les Clefs de la Suède. Paris: Hachette, 1935.

Evensmo, Sigurd. “Arme mr. Butler.” Arbeiderbladet, July 8, 1935.

Evensmo, Sigurd. "Selsom revy over verden i nød: Arbeidskonferansen i Genevesett fra galleriet." Arbeiderbladet, June 29, 1935.

"Frankrike studerar svenska arbetsförhållanden." Aftonbladet, July 13, 1938.

Gjesdal, Tor. “Nordiske 'misjonærer' lærer Frankrike folkeskikk i arbeidslivet.” Arbeiderbladet, July 9, 1938.

Guesde, Jules. "Voyage en pays scandinaves: Au libre et démocratique Danemark." Le Populaire, October 11, 1937.

Heiberg, Inger. “Lærdom for livet...” In Vi valgte fransk. Fransk på norsk grunn, edited by Asbjørn Aarnes and Magne Skodvin, 57-72. Oslo: Universitetsforlaget, 1986.

Hesselgren, Kerstin. "Nordiska folkhögskolan i Genève." Mellanfolkligt samarbete 2, 1935.

H-th., H. "Franska frågor i mängd vid Pontignymötet." Svenska Dagbladet, June 28, 1938.

Krabbe, Ludvig. "Nordiska folkhögskolan i Genève. Folkhöjskolens tredje kurs.” Mellanfolkligt samarbete 10, December, 1933.

Lefranc, Georges. Preface to Visite aux Ouvriers Scandinaves, by Georges Albertini, 1-11. Paris: Conférences de l'Institut supérieur ouvrier, 1938.

Mellesmo, Arne. "Med Nordiske Folkehøgskole til Geneve." Dagningen, June 30, 1939.

Millet, Raymond. "La leçon que nous ont apportée syndicalistes et patrons suédois." Le Temps, June 20, 1938.

Nationen. "Folkeskolens budgett vedtatt." April 4, 1936.

Nilsson, Karl. "Från Nordiska folkhögskolan i Genève." Mellanfolkligt samarbete, May, 1931, 57-58.

Nilsson, Karl. “Kring Genèveskolan.” Mellanfolkligt samarbete 7, November 1931.

"Ny värdsartikel?" Metallarbetaren, July 6, 1938.

O-l. "I problemene og motsetningenes verdenssentrum. Reisebrev fra Geneve." 1ste Mai, June 22, 1935.

O-l. "Inntrykk—overraskelser-oplevelser: Reisebrev fra Geneve." 1ste Mai, June 28, 1935.

Paraf, Pierre. Clartés d'Europe. Paris: Editions R.-A. Corrêa, 1935.

Planus, Paul. Patrons et ouvriers en Suède: vers la paix sociale. Paris: Plon, 1938

"Pontigny gav impulser till fortsatt samarbete i Frankrike." Arbetet, July 4, 1938.

Rodrigues, Gustave. "Pontigny, centre de trahison ouvrière.” Nouvel Age, July 4, 1938.

Sandås, Hans. 'Geneve- 'Verdens hovedstad:' Litt om arbeidsbyrået og dets virksomhet." Sarpsborg Arbeiderblad, July 24, 1939. 
Sandås, Hans. "Små sluttbemerkninger om Folkehøiskolen i Genève, og litt om de spanske flyktninger." Sarpsborg Arbeiderblad, August 15, 1939.

Skodvin, Magne. "Paul Desjardins og nordmennene i Pontigny." In Fransk i Norge, edited by Anna-Lisa Amadou et al, 139-48. Oslo: Aschehoug, 1975.

Skodvin, Magne. “"Jeg valgte fransk... »." In Vi valgte fransk: Fransk på norsk grunn, edited by Asbjørn Aarnes and Magne Skodvin, 97-99. Oslo: Universitetsforlaget, 1986.

Vandervelde, Émile. "La Scandinavie rouge.” La Dépêche de Toulouse, January 15, 1936.

Valois, Georges. "La charte d’Amiens déchirée." Nouvel Age, July 5, 1938.

"Vekst og grotid for samholdstanken i Norden." Arbeiderbladet, October 26, 1936.

\section{Literature}

Casanova, Pascale. La république mondiale des lettres. Paris: Seuil, 1999.

Chaubet, François. Paul Desjardins et les Décades de Pontigny. Paris: Presses universitaires du Septentrion, 2000.

Clavin, Patricia and Glenda Sluga. "Rethinking the History of Internationalism." In Internationalisms: A Twentieth-Century History, edited by Patricia Clavin and Glenda Sluga, 3-14. Cambridge: Cambridge University Press, 2017.

Dard, Olivier. Le rendez-vous manqué des années 30. Paris: Presses Universitaires de France, 2002.

Denord, François. "French Neoliberalism and Its Divisions: From the Colloque Walter Lippmann to the Fifth Republic." In The Road from Mont Pèlerin: The Making of the Neoliberal Thought Collective, edited by Philip Mirowski and Dieter Plehwe, 45-67. Harvard University Press: Cambridge, Massachusetts, 2009.

Dogliani, Patrizia. “The Fate of Socialist Internationalism.” In Internationalisms: A Twentieth-Century History, edited by Patricia Clavin and Glenda Sluga, 38-60. Cambridge: Cambridge University Press, 2017.

Glover, Nikolas and Andreas Mørkved Hellenes. “"'A 'Swedish Offensive’ at the World's Fairs: Advertising, Social Reformism and the Roots of Official Swedish Cultural Diplomacy, 1935-1939." Contemporary European History (forthcoming, 2020).

Götz, Norbert. "Blue-Eyed Angels' at the League of Nations: The Genevese Construction of Norden." In Regional Cooperation and International Organizations: The Nordic Model in Transnational Alignment, edited by Norbert Götz and Heidi Haggrén, 25-46. London: Routledge, 2009.

Gram-Skjoldager, Karen, Haakon A. Ikonomou and Torsten Kahlert. "Scandinavians and the League of Nations Secretariat, 1919-1946." Scandinavian Journal of History 44, no. 4 (2019), 454-83.

Grinell, Klas. Att sälja världen: Omvärldsbilder i svensk utlandsturism. Göteborg: Acta Universitatis Gothoburgensis, 2004.

Gråbacke, Carina. När folket tog semester: Studier av Reso, 1937-77. Lund: Sekel, 2008.

Heldal, Halldor. "Den lange veien til Genève: Norsk arbeiderbevegelse og ILO 19201934." Arbeiderhistorie 5 (1992), 81-106.

Hellenes, Andreas Mørkved. Fabricating Sweden: Studies of Swedish public diplomacy in France from the 1930s to the 1990s. PhD diss., Sciences Po Paris \& University of Oslo, 2019.

Hemstad, Ruth. "Scandinavianism, Nordic Co-operation, and 'Nordic Democracy"' In Rhetorics of Nordic Democracy, edited by Jussi Kurunmäki and Johan Strang, 179-93. Helsinki: Finnish Literature Society, 2010. 
Hilson, Mary. "Consumer Co-operation and Economic Crisis: The 1936 Roosevelt Inquiry on Co-operative Enterprise and the Emergence of the Nordic 'Middle Way"' Contemporary European History 22, no. 2 (2013), 181-98.

Hilson, Mary. "Popular Movements and the Fragility of the Nordic Democracies During the First Half of the Twentieth Century." Journal of Modern European History 17, no. 4, (2019), 469-85.

Hilson, Mary, Silke Neunsinger, Iben Vyff and Ragnheidur Kristjánsdóttir. "Labour, Unions and Politics in the Nordic Countries, c. 1700-2000: Introduction." In Labour, Unions and Politics under the North Star: The Nordic Countries, 1700-2000, edited by Mary Hilson, Silke Neunsinger and Iben Vyff, 1-70. New York/Oxford: Berghahn Books, 2017.

Hirdman, Yvonne. Den röda grevinnan: En europeisk historia. Stockholm: Ordfront, 2010.

Horn, Gerd-Rainer. "From 'Radical' to 'Realist:' Hendrik de Man and the International Plan Conferences at Pontigny and Geneva, 1934-1937." Contemporary European History 10, no. 2 (2001), 239-65.

Imlay, Talbot C. "Socialist Internationalism after 1914." In Internationalisms: A Twentieth-Century History, edited by Patricia Clavin and Glenda Sluga, 213-42. Cambridge: Cambridge University Press, 2017.

Imlay, Talbot C. The Practice of Socialist Internationalism: European Socialists and International Politics, 1914-1960. Oxford: Oxford University Press, 2017.

Jansson, Jenny. "Class Formation in Sweden and Britain: Educating Workers." International Labor and Working-Class History 90, Fall 2016, 52-69.

Kettunen, Pauli. "The Power of International Comparison: a Perspective on the Making and Challenging of the Nordic Welfare State." In The Nordic Welfare State: A Historical Reappraisal, edited by Niels Finn Christiansen, Nils Edling, Per Haave and Klaus Petersen, 31-65. Copenhagen: Museum Tusculanum, 2006.

Kettunen, Pauli. "The ILO as a Forum for Developing and Demonstrating a Nordic Model.” In Globalizing Social Rights. The International Labour Organization and Beyond, edited by Sandrine Kott and Joëlle Droux, 210-30. London: Palgrave Macmillan, 2013.

Kurunmäki, Jussi. "Nordic Democracy' in 1935. On the Finnish and Swedish Rhetoric of Democracy." In Rhetorics of Nordic Democracy, edited by Jussi Kurunmäki and Johan Strang, 37-82. Helsinki: Finnish Literature Society, 2010.

Kurunmäki, Jussi and Johan Strang. "Introduction: 'Nordic Democracy' in a World of Tensions." In Rhetorics of Nordic Democracy, edited by Jussi Kurunmäki and Johan Strang, 9-36. Helsinki: Finnish Literature Society, 2010.

Laqua, Daniel. "Democratic Politics and the League of Nations: The Labour and Socialist International as a Protagonist of Interwar Internationalism." Contemporary European History 24, no. 2 (2015), 175-92.

Leppänen, Katarina. "Education for Internationalism at the Nordic school for Adult Education in Geneva 1931-1939." History of Education 40, no. 5 (2011), 635-49.

Marklund, Carl and Klaus Petersen. "Return to Sender: American Images of the Nordic Welfare State and Nordic Welfare State Branding." European Journal of Scandinavian Studies 43, no. 2, 2013, 244-256.

Maul, Daniel. The International Labour Organization: 100 Years of Global Social Policy. Berlin/Boston: De Gruyter, 2019. 
Milani, Tommaso. "Les Belles Années du Plan?" Hendrik de Man and the Reinvention of Western European Socialism, 1914-36 ca. PhD diss., London School of Economics and Political Science, 2018.

Musiał, Kazimierz. Roots of the Scandinavian Model: Images of Progress in the Era of Modernisation. Baden-Baden: Nomos-Verlag, 2002.

Nygård, Stefan and Johan Strang. "Facing Asymmetry: Nordic Intellectuals and Center-Periphery Dynamics in European Cultural Space." Journal of the History of Ideas 77, no. 1, (2016), 75-97.

Österberg, Mirja. “'Norden' as a Transnational Space in the 1930s: Negotiated Consensus of 'Nordicness' in the Nordic Cooperation Committee of the Labour Movement." In Labour, Unions and Politics under the North Star. The Nordic Countries, 1700-2000, edited by Mary Hilson, Silke Neunsinger and Iben Vyff, 237-57. New York/Oxford: Berghahn Books, 2017.

Patel, Kiran Klaus. "How America Discovered Sweden." In Transatlantic Democracy in the Twentieth Century: Transfer and Transformation, edited by Paul Nolte, 75-89. De Gruyter Oldenbourg: Berlin, 2016.

Petersen, Klaus. "Constructing Nordic Welfare? Nordic Social Political Cooperation 1919-1955." In The Nordic Welfare State: A Historical Reappraisal, edited by Niels Finn Christiansen, Nils Edling, Per Haave and Klaus Petersen, 67-98. Copenhagen: Museum Tusculanum, 2006.

Reijnen, Carlos and Marleen Rensen. "Introduction: European Encounters, Intellectual Exchange and the Rethinking of Europe." European Studies 32 (2014), 13-30.

Rom-Jensen, Byron. "A Model of Social Security? The political usage of Scandinavia in Roosevelt's New Deal." Scandinavian Journal of History 42, no. 4, 2017, 363-88.

Sluga, Glenda. Internationalism in the Age of Nationalism. Philadelphia: University of Pennsylvania Press, 2013.

Stadius, Peter. "Happy Countries: Appraisals of Interwar Nordic Societies." In Communicating the North. Media Structures and Images in the Making of the Nordic Region, edited by Jonas Harvard and Peter Stadius, 241-62. London: Routledge, 2013.

Steine, Bjørn Are. "Mellom nasjonale ambisjoner, intellektuelt samarbeid og amerikansk filantropi. Forsøkene på å etablere internasjonale studier som vitenskapsdisiplin i Skandinavia før andre verdenskrig." Internasjonal Politikk 70, no. 1, (2012), 35-61.

Steiner, Zara. The Lights that Failed: European International History 1919-1933. Oxford: Oxford University Press, 2005.

Stråth, Bo. "The Swedish Image of Europe as the Other." In Europe and the Other and Europe as the Other, edited by Bo Stråth, 359-20. Brussels: P.I.E.-Peter Lang, 2000. 